\title{
LEGAL CULTURE AND SOCIAL DEVELOPMENT
}

\author{
By LaWRENCE M. FrIEdMaN*
}

\section{Introduction: The Problem Stated}

In recent years, a lot of scholarly research and thought have been directed toward political, social and economic development. What aspects of national culture lead a society toward rapid economic growth and a high standard of living? What are the sources of stable government? Why are some countries rich and some poor? Why do some have strong governments, and others weak ones? It is not difficult to guess why these kinds of questions seem urgent. The old colonial empires have fallen apart or been blown apart. Since the end of the second World War, scores of new nations, mostly very poor but very ambitious, have gained independence. But the problems and the dreams of new nations are probably only a special case of problems and dreams common to all modern societies. And if there are social laws of development to be discovered, they would presumably apply to old and new countries, to dead empires as well as to living micro-states. This point is, in general, readily conceded by the scholars, who are off in hot pursuit of a general social science of development and change.

Legal scholars come to the problem of development somewhat tardy. But legal systems are clearly a part of political, social and economic development, just as is true of educational systems and other parts of the culture. No major social change occurs or is put in effect in a society, which is not reflected in some kind of change in its law. Legal institutions are responsive to social change; moreover, they have a definite role, rather poorly understood, as instruments that set off, monitor, or otherwise regulate the fact or the pace of social change. But beyond these mountainous generalities, there has been surprisingly little said about development and law as a whole. Many basic questions of the relationship of law to social change and to cultural development are completely neglected. Does the type of legal system and legal institutions that a society uses help or hinder that society in its march toward modernization? How does law influence the rate of economic growth? How does law brighten or darken the road to political wisdom or stability? How can a society improve its system of justice? What happens when laws are borrowed from more „advanced“ countries? Under what conditions will these borrowings be effective, under what conditions will they wilt and die in alien soil?

Comparative law is a recognized, traditional field of legal learning; but its usual strategy of research has not led it to touch on these questions in any systematic way. The persons who have been interested in law and development, and in the larger questions of culture, history, and law, have not classified themselves as comparativists in the traditional sense. Their questions belong outside of the field of comparative law as hitherto understood; they belong to a new field of study only now in the process of emerging. This fresh-born field,

\footnotetext{
* This is a revised version of a paper originally delivered as part of a panel discussion sponsored by the Association of American Law Schools at its meeting in December 1968 in New Orleans, Louisiana, U.S.A. I wish to thank Robert Alford, Daniel Lev, Marc Galanter, Carl Spaeth, and David Trubek, whose comments on earlier drafts were enormously helpful. This paper contains no citations to authorities. The reader will nonetheless recognize my indebtedness to a whole line of political and social scientists, whose influence is felt at many places.
} 
which aims to explore general connections between law, culture, and development, so far lacks a name and a shape of its own. Its literature is fragmentary, at best. It is full of false starts and blind alleys. Max Weber probed the connection between the rise of capitalism, modern rationalism, and the legal order, at the dawn of modern sociology. Unfortunately neither sociology, nor political science, nor history, nor economics, nor law, has carried Weber's line of thought much further. In general, sociology and anthropology of law have had quite a different emphasis and aim. Work on specific societies, and on specific needs of the developing countries is sometimes quite relevant to the broader questions of culture, history, and law - studies, for example, of land tenure reform, the modernization of family law, or the adaptation of a Western code in a non-Western land. But these studies remain, by and large, isolated in their own geographic departments. A few scholars have wondered aloud about the impact of Western courts and procedures on non-Western cultures. But this work too has been, from the standpoint of general theory, rather fragmentary and disjointed. In short, there is a lot of intriguing work and data; but it is scattered and unclassified, hard to find, and hard to put together.

There are, of course, tremendous obstacles that stand in the way of developing general theory about law and development. Cross-disciplinary work is hard enough; cross-cultural work compounds the difficulty. Since Weber, few scholars have had a grasp of history, law, economics, and sociology equal to the task. Few legal scholars are trained in the social science, few have the necessary language abilities. Legal education, in Western countries, is oriented toward training lawyers in their craft, chiefly by teaching doctrine and by inculcating legal skills. American law schools have been predominantly concerned with American law - almost of necessity. The social scientists are even more seriously handicapped. They find law and its language very formidable. In Western societies, legal systems have grown to monstrous size. They constitute inbred, highly technical information systems. In non-Western societies, empirical data on law is hard to come by. Foreign law is a Babel of tongues and a statistical desert. Moreover, social scientists take their definitions of law from the lawyers; hence they do not relate what they find about the economics and social control mechanisms of various cultures, to what they put in a separate box labelled law. The field, then, is difficult; but this merely means that it cries out for collaborative efforts, by scholars with different specialties and skills, sharing information, and helping each other in design and execution of research.

It could also be argued that law and development are not ripe for theory. What is necessary is a lot more patient work on particulars. Patient work on particulars, to be sure, is sorely needed. But this work would be enormously more efficient if it were guided by some general theory. In fact, no work is possible without some ruling concepts or propositions. The point is that these concepts and propositions do exist, as assumptions, superstitions, half-formed notions. What needs to be done is to collect them, bring them to the surface, test them, and separate the good from the bad. There was an implicit theory of law and development, or part of one, in Ataturk's mind when he imported the Swiss Civil Code into Turkey. Something of the same theory is at work in the new African states, or seems to be. There is some sort of theory, disguised or implicit, in the work done by law schools and legal professionals in underdeveloped countries all over the world - and probably in any work of law reform that they do at home. 
This paper does not pretend to move toward a general theory of law and development. It merely aims at clarity in a few concepts that seem to be important in the process of building such a theory.

\section{The Concept of a Legal System}

The idea of law implies a group of people subject to governance by law. There is debate, whether one can find some absolute minimum in formal institutions, below which one cannot say that a system is legal at all. Are there societies so simple that they lack legal norms and legal institutions? This debate is not relevant for our purposes. Highly organized societies do have law and legal systems. These societies are characterized by a great deal of social division of labor. The have separate, distinct, and highly specialized institutions, to make and administer law.

In the modern world, the boundaries between legal systems are largely territorial. Legal power follows political lines, and is divided into jurisdictions. Every independent country has its own body of laws. Many have more than one, for example, federations. Many countries are or have been legally plural without being federal. In most African countries, the law of the colonial masters applied most completely to those parts of society which had adopted Western ways and which took part in some kind of market economy. In the interior, native ethnic groups settled disputes through the use of so-called customary law, which differed from the law applied at the center, even when judges sent out from the center applied it. In the old Ottoman Empire, each ethnic group enjoyed its own family law and its own system of courts.

Every body of laws, together with its supporting institutions, whether national or part of a federal or pluralistic system, can be called, somewhat loosely, a legal system. One can speak of the federal law of the United States, and also of the legal systems of Colorado, Florida, and Maine. National legal systems in turn can be grouped and classified into larger units, or families of law, also loosely called „legal systems". One speaks, for example, of the common law legal system, in England, the United States and most of the English-speaking world, and the civil law system of France, Germany, Italy, and Spain.

Classification of legal systems into families assumes that national legal systems are more than the sum of their parts; that they have a definite character and style. In the families of law, all members share certain basic legal traits. These traits or characteristics are consistent with each other, persist over time, and permeate the legal institutions of the society in such a way as to give the legal system a definite flavor or character. The classifiers, like taxonomists in biology and linguistics, single out certain basic or core features as diagnostic. The core features are then used to assign a body of law to this or that "system". The diagnostic features tend to be highly "legal". That is, they pertain to those parts of law which are most exclusively controlled by lawyers, or which, for some reason of history or social position of the profession, loom large in lawyer's minds and are stressed in their training. If one asked a traditional legal scholar how a common law system - like that of some American state - was different from the law of Italy or France, he might mention the doctrine of precedent, point out that American law is not wholly codified, refer to the civil jury, and perhaps mention a few concepts, such as consideration in the law of contracts all these as opposed to the civil law system. 
But no one singled out these traits because they were known to be important to the way the law actually operates in contemporary times. The traits, the typology, the classification scheme are based on historical evolution. To be sure, evolutionary theories have yielded useful classifications in linguistics and biology. This has been the model for the classification of systems of law. But what is the utility of the evolutionary scheme as the basis for classification and evaluation of legal systems? Of course, it is true that in one interesting sense, American law "descends" from English law and the law of Louisiana from the civil law of France and Spain. But does the language of evolution, and the typology that results, explain anything, except the formal sources of those traits selected as "basic"? Moreover, the traits were selected as basic precisely because they were valuable to the classification scheme. Does classification of legal systems by the historical evolutionary method tell us anything about ot he r characteristics of a nation or society? Is there a causal connection between membership in one of these families and some level of social or economic development? Many scholars have speculated on this general subject; it was, in a way, one of Max Weber's central themes. It is fair to say that nothing has been proven. The jury is a common law institution, for example. Through jury service, ordinary people make law, or at least take part in decisions. Does this kind of participation in law mean that the jury is vital to the growth of democratic government? It would be rash indeed to answer with too bold a yes. That would mean that systems without a jury would be less likely to evolve democratic institutions, or to keep them, than systems that had a jury. Not enough is known about the effect of this kind of participation on the political system. Perhaps there is some functional equivalent to the jury in systems that do not exactly have a jury. Perhaps the actual impact of a jury is far less democratic than it seems. Some countries with juries seem less participatory than some countries without juries. Similar doubts can be expressed about a $\mathrm{n} y$ of the diagnostic features of the traditional classification - and about the features as a whole. One simply cannot say that the common law system, as it evolved in England, was a decisive factor in the rise of the English form of government. Even less could one say that it had anything to do with the flowering of the industrial revolution. Could we even say that it contributed to economic or political change? And what does it do today? What would it do in Burma or Iran?

Notice that our skepticism was limited to the common law "system". We neither asserted nor denied that English $1 \mathrm{a} \mathrm{w}$ had an influence on political or economic development in England. We drew a sharp line between what is conventionally called the common law system, and English law (or the English legal system), which is something broader and quite different. All we are saying, for now, is that the conventional concept of the legal system, based on historical evolution, is not a helpful tool of research and theory, if the purpose of classifying bodies of law and generalizing about them is to understand the relationship between law and society. This is so, for at least two reasons. First, the conventional concept does not do an adequate job of describing how legal systems work. The traits it singles out have not been tested empirically for their impact on the economy, the political system, or on society in general. Second, the conventional concept does not presuppose or yield any coherent theory of the relationship of law and society. It may even be inimical to development of such a theory. 


\section{The Legal System: Toward a New Definition}

Very often, when people speak of "the legal system" of their community, they are not thinking of that static bundle of traits traditionally used to classify legal systems. They are speaking rather of concrete activities going on about them. They are thinking of lawyers and judges at work, legislators passing laws, administrative agencies making rules and settling disputes. One way to look at the legal system is as a process - what legal institutions do, and how they do it. This is one meaning of the word "system" in modern social science - an actual operating unit in the social system, which takes in raw materials, processes them, and produces an output. The comparison between the legal system and a machine is vulgar but useful. It directs our attention to actual moving parts. In these terms, study of the legal system would include study, first of all, of the demands made upon legal institutions, calling for action of one sort of another; second, the responses made by legal institutions; third, the impact and effect of these responses on the persons making the demands, and on society as a whole.

The concept of "demand", as used here, is broader than its general use. Any request for action or redress of grievance, any use of legal or administrative process is a demand. Litigation is a demand made upon a court. When one or more persons bring a law-suit, they are asking for a response from the court as well as from the defendant. The defendant too can be looked upon as making a demand upon the court; he demands justice or vindication. Even if the court dismisses the case or refuses jurisdiction, it has made a response. And whatever response it makes, has an impact on the particular litigants, and very often further. The legal system as a whole consists of the universe of demands upon legal institutions not only courts, of course - together with the responses and the effects of the responses. The current social meaning of a legal system can be discovered only if one has some idea what these institutions, demands, and responses are, and some notion of their quality and quantity.

A working legal system can be analyzed further into three kinds of components. Some are structural. By structural, we mean the institutions themselves, the forms they take, and the processes that they perform. Structure includes the number and type of courts, presence or absence of a constitution, presence or absence of federalism or pluralism, division of powers between judges, legislatures, governors, kings, juries, administrative officers; modes of procedure in various institutions; and the like. Other elements in the system are cultural. These are the values and attitudes which bind the system together, and which determine the place of the legal system in the culture of the society as a whole. What kind of training and habits do the lawyers and judges have? What do people think of law? Do groups or individuals willingly go to court? For what purposes do people turn to lawyers, for what purposes do they make use of other officials and intermediaries? Is there respect for law, government, tradition? What is the relationship between class structure and the use or non-use of legal institutions? What informal social controls exist in addition to or in place of formal ones? Who prefers which kind of controls, and why?

These aspects of law - the legal culture - influence all of the legal system. But they are particularly important as the source of the demands made upon the system. It is the legal culture, that is, the network of values and attitudes relating to law, which determines when and why and where people turn to the law, or to government, or turn away. 
Still other components are $\mathrm{substantive.} \mathrm{This} \mathrm{is} \mathrm{the} \mathrm{output} \mathrm{side} \mathrm{of} \mathrm{the} \mathrm{legal}$ system. These are the "laws" themselves - the rules, doctrines, statutes and decrees, to the extent they are actually used by the rulers and the ruled; and, in addition, all other rules which govern, whatever their formal status.

The three elements together - structural, cultural, and substantive - make up a totality which, for want of a better term, we will call the legal system. The living law of a society, its le gal system in this revised sense, is the law as actual process. It is the way in which structural, cultural, and substantive elements interact with each other, under the influence too, of external, s it u a $\mathrm{t}$ i o $\mathrm{n}$ a $\mathrm{l}$ factors, pressing in from the larger society.

In this revised definition, the key concept, perhaps, is that of the legal culture. People are quite accustomed to comparing the outer forms of legal structures and substantive law. They fall into error when they fail to distinguish between mere paper systems and reality; between dead rules and institutions, and living ones. Hence they may be enormously misguided in their view of a country's legal system, even from the structural or the substantive viewpoint. But even this mistake is a mistake with respect to the legal culture. This is so, because legal culture is the term we apply to those values and attitudes in society which determine what structures are used and why; which rules work and which do not, and why.

Legal cultures obviously differ in ways that cut across the conventional similarities and differences of legal systems, classified by historical evolution; so, therefore, do legal systems differ.

Louisiana, for example, is said to belong to the civil law family. By convention, this makes it a close relative of the legal system of France; and a stranger to the system of its sister states. Yet the cultural elements of Louisiana's legal life undoubtedly are closer to those of Arkansas or Texas than to France. The number of lawyers and judges, the jobs they do, their place in Louisiana society, what the public thinks of law and lawyers, the kinds of disputes that go to court and stay out of court - these are probably very similar in Louisiana's neighboring states, and quite different in France. Actually, culture is only the most striking case. The textbooks sharply distinguish the substance of Louisiana law from the law of Mississippi, stressing historical and diagnostic traits. Yet the laws of the two states are not that different, if we look instead at the working law of social and economic life: tax law, economic regulation, the law of race relations, occupational licensing, labor codes. Federal law, of course, is identical in the two states, and it is of great importance. French tax and regulatory law, on the other hand, are quite remote from Louisiana. Even the structural elements of law in Louisiana are closer to those of its neighboring states than one might expect from traditional theory. The states are parts of a federal system; all are subject to the constitution. They have shared a century and a half of a common history; they are all part of a single large free-trade area, the United States. Population streams freely across borders; and so the public image of law tends to be much the same in Louisiana and its neighboring states. Finally, Louisiana lawyers speak English; in their training they are exposed to the influence of common law institutions. Hence the legal systems, as a whole, are very similar in neighboring states.

Contrariwise, two members of what was historically one legal family may move along separate paths as their societies diverge. American law obviously owes a great deal to English law. But British and American law have grown significantly apart over the last three centuries. A great deal of the actual working law in a 
mature, industrial society is comparatively new law; and it is comparatively specific to the country. In the United States, this includes a vast sea of regulatory law, tax law, labor law, insurance and corporation law, welfare and planning law, and an enormous body of administrative rules and codes. Regulatory and planning law are vital parts of the legal system. They provide a good share of the daily business of lawyers and government officials. They are obviously of first importance in economic and social development. Comparative legal studies traditionally paid little attention to these modern aspects of law. But these parts of law, because they are living, and important, are part of the legal culture, and are deeply rooted in the culture of the society as a whole. They cannot be ignored if one is interested in principles that may explain the relationship of law and the process of social growth.

A comparison of British and American law, for example, would no doubt yield important differences in legal culture, which affect the way. in which the rules of law have been elaborated, and the way in which institutions work. The rules, of course, are different; and so are the institutions. But these are probably only the outer form of underlying differences in style, in the effect of public opinion, in short, in culture. What these are, exactly, is a subject for research. The possibilities are intriguing. In England, the statutes that govern land use are broadly worded. They vest enormous power in local authorities; judicial review of land use decisions is rare and ineffective. By way of contrast, the United States is the homeland of $\mathrm{z}$ o n in $\mathrm{g}-$ a rigid, specific mode of land use control. Cities enact a land use map which determines, for considerable periods of time, the fate of particular parcels of land. On the other hand, landowners can get "variances"; and zoning decisions may be reviewed in court, and are, with some frequency.

There are other differences between the two countries which seem to run parallel to the differences in land use control. There seems to be an American attitude toward law and toward power, which fears centralization and likes to split authority into fragments which counterbalance each other. This cultural attitude, perhaps, explains the rejection here of the English style of planning law. American law, at least in this area, seems to prefer to control agencies collaterally, so to speak; English law seems to prefer control through hierarchy, with a regular chain of command. It does not necessarily follow, however, that the ou t come s of land use control in the two countries are necessarily different. That depends in turn on the substance of the law (though in the living-law, not the formal-law sense). And any "gap" between theory and practice will turn out to be influenced by the legal culture, that is, by the values and attitudes of the rulers and the ruled.

Distinguishing between the two definitions of legal system - one historical and evolutionary, one based on a process model and stressing the legal culture may bring some clarity into discussion of general theoretical questions of the relationship between law and society. There are a number of extreme positions that stand in contrast to each other. One position is that the law. is insulated from the general social system. It is not culturally specific, but is rather adaptable to any level of social development. The legal system has habits, and embodies values; but these habits and values, reduced to essentials, are timeless; different legal systems are different ways of looking at the world that are in eternal dialogue. Law, then, is analogues to language, which is another rather insulated social phenomenon. The Japanese speak Japanese now, in the midst of their economic miracle, just as they spoke Japanese in the middle ages. 
French is spoken in France, a rich, sophisticated, urban country; it is spoken, too, in rural, backward Haiti. French, like all languages, can invent or adopt new words; it can assimilate changes in technology or art or thought, without a significant time lag, or serious social disruption. Japanese adapts itself to the modern world without fundamental structural change. Legal systems can be looked at in the same way. Edward I and Elizabeth II reigned in a country that was English-speaking and professed the common law. For a thousand years, the common law maintained some sort of continuity, while absorbing and responding to the most fundamental kinds of social change. Law, in this view, is a tough, persistent, relatively self-contained social subsystem. It can accomodate itself to social change, of course, but its basic structure is firm and tenacious.

Another extreme position asserts that a system or body of law is tied to specific levels or kinds of culture. Law ist not self-contained; it is culturally very specific. If a community wants to put through some program of drastic political and economic change, it must make drastic changes in its laws. If it wants to modernize, and especially if it wants to modernize fast, the legal system has to be radically altered, or even replaced. Some scholars, for example, might argue that the new African nations must stamp out all traces of customary law, not merely in the name of national unity, but also because customary law is incompatible with modern agriculture, business, and trade, and with the modern state. They do not look on customary law as containing any values worth preserving or as providing any basis for adaptation to modern needs. In most of Africa and much of Asia, colonial powers introduced some parts of the law of the mother country; and this law had some effect, at least on the upper class in the colonial capital. The new nations, however, have been scarecely less avid than the colonials in seeking legal models outside of their own experience. Mostly these have been Western models, sometimes Socialist models. In either case, they have acted on the assumption that only these models are conducive to the kind of economic growth they want.

There are many other ways of looking at legal systems and their relationship to the larger society, and many hybrid views. Most of them rest on observations that are undeniably true in part. The various theories simply assume different conceptions of the legal system. It is certainly true that legal systems, in the historical and evolutionary sense, are tough and persistent; and can be adapted to societies of quite different types and levels of culture. France and Haiti share a "legal system" as well as a language. It is also clear that any radical social change implies a radical change in the law. When a community moves from tribal organization to nationhood and a money economy, the legal organization of the community will have to be changed, to implement and support the new political, social, and economic realities. If the legal tradition does not support these programs, new law - sometimes in massive doses - must be manufactured or brought in from outside.

These general points suggest that discussion of the relationship between the legal system and social development does well to begin by asking what is meant by the legal system. As far as we know, any of the great historical evolutionary families is c a pable of supporting any level of economy or culture. But this point is not very helpful because all that it means is that over a long enough time-period, legal institutions can accommodate themselves to a variety of social arrangements. Ist also requires us to define "legal institutions" very narrowly, using, as tools of difinition, criteria which do not relate to the question 
at hand. On the other hand, legal systems are not collections of brittle little sticks, to be picked up and discarded at the command of the rulers. Some parts of the living law are deeply imbedded in national culture. To replace major parts of it either means to uproot something quite fundamental, at considerable costs in disruption; or face the possibility that new law will lapse into ineffective life. What the study of legal culture promises is the discovery of the conditions under which legal change occurs, either spontaneous change, or imposed change; and, in the case of imposed change, the conditions which make it fail or succeed.

\section{Stability and Change in the Law}

This is an age, by common consent, of rapid and continuous social change. On the legal side, it is an age which is interested, as few periods have been before, in law reform and in social reform through law. This means that those who are concerned, as legal scholars or social scientists, with the working of the legal system, will probably have to pay increasing attention to that aspect of the legal system which we have called legal culture. We wish to suggest, first, that the idea of social engineering through law is itself an important aspect of the legal culture; second, that this means turning scholarly attention to the question of the conditions under which law is "effective". Here, again, we meet with the legal culture as a critical variable.

On the first point: it hardly needs to be demonstrated that modern societies, as opposed to those societies which we call primitive or traditional, are changeoriented. This means not only that they are changing, but also that they w a $\mathrm{t}$ to change. The public as a whole, or some significant elite, has the attitude that change is necessary and desirable, and that the state, the government, the authorities, have the duty to put programs into effect that will move society in the proper direction. In this respect, all modern societies are alike. Whatever vast differences separate the laissez-faire governments of the 19th century from the government of Maoist China, to take two extreme examples, this cultural attitude is held in common. Modern societies share a belief in the directive power of government and law. They have different definitions of law. They have different philosophies of law. But they all believe in the duty of the authorities to put in operation effective programs that allow or push society toward the goals they see for society. No modern society believes absolutely in the fixity and permanence of law. They may believe in some absolutes, whether the bill of rights, the ban on birth control, or the inviolability of Marx; but they all assume that there is a sphere of human life in which governments can act and must act on behalf of the common good. Demands for change are addressed to governments. It is the rulers who must respond. They, not the gods, must bring on the magic.

The question of effectiveness is more difficult. In one sense legal institutions are effective if society is stable, that is, if the demand side and the supply side of the legal system are in some sort of equilibrium. They are effective at least in the sense that they keep society going without a major breakdown. In some societies, it is easy to see this equilibrium. This is true of static or traditional societies. Members of the community make demands on public authorities, of course; grievances are addressed to chiefs, or bureaucrats; trouble cases go to court. But these demands are routinely handled. They put no unbearable stress on legal institutions, or on 
the general structure of society. The capacity of the authorities - their ability to meet routine demands - is sufficient to keep the society in a steady state. Equilibrium is not only a characteristic of primitive or traditional peoples. Ordinary legal process, even in complex societies, shows this trait. The traffic court judge comes to court and does his job, day in and day out. Demands flow in, decisions flow out, fines flow in, flagrant violators go to jail, drivers with good stories get off free. The system is stable, and, in its own terms, effective. Probably the whole court system in Western countries is stable and effective in this sense.

But courts are only part of the picture. Today all complex societies are changeoriented. Demands are made on all legal institutions; and the demands are demands for progress, improvement, reallocation, reform. This factor on the demand side - a push toward change - does not necessarily mean that modern governments live in a perpetual state of political or legal crisis. Stable governments are not changeless governments, in the modern world, but governments which are lucky enough or sound enough to find ways to satisfy the most pressing demands made upon them. Their legal system are equilibrium systems, in the sense that they are stable. But they differ from the simpler equilibrium of traditional society, in that they accept, process, and produce change, just as a functioning market system accepts, processes and produces outputs that reflect all sorts of changes in consumer demand. The restlessness of twentieth century life, then, does not necessarily mean a state of crisis. But often enough crisis does come. Some intrusive force, some novelty occurs, and the number or type of demands is thrown out of balance. There may be, for example, demands from some economic class for a higher national income, or for better distribution of the country's wealth; and such demands, whether they stem only from a Westernized elite, or from the mass of the people, desirous of better food, more bicycles, or a greater say in their lives, very often cannot be met without radically changing society. Nor are radical demands by any means confined to the less developed nations.

On the supply side, then, the critical question is whether the legal system is responsive enough or effective enough, measured by some ideal, or end product, or goal. There is no such thing as effectiveness in the abstract. Effectiveness may be judged from the inside of the system - does the system s u r vive without overthrow, does it satisfy its own customers? Or effectiveness may be judged by some outside ideal or product, whether an abstract product (justice), or some concrete goal, like a lower crime rate or higher amount of wealth. Once effectiveness is concretely defined, however, it is possible to compare legal systems in terms of such a concept.

\section{Legal Culture and the Effectiveness of Law}

At the present time, legal research is in no position to identify legal factors that make for successful economic development, for political stability, or indeed for any reasonable measure of the effectiveness of law. For one thing, no country, not even the United States, has an accurate bank of quantitative information about its legal system. For non-Western countries there is even less information. Not even such simple things as the number of lawyers is known for many countries. But an accurate description, or "map" of the legal system, is vitally important for generating comparative social theory, and for learning the conditions under which legal systems work and fail. What is most notably missing, 
even for the Western countries, is information on what we have called the legal culture. What are the attitudes of different populations toward various parts of the legal system? Are courts used or avoided? Who goes to court and why? What legal roles - lawyers, judges, policemen - exist in society? Who occupies these roles and what functions do they perform? What is the conversion process of the legal system, that is, how are demands handled, by whom; how are decisions made? Which officials have discretion, which do not? What questions are matters of rule, and what questions are matters of discretion? Are various parts of the system bureaucratic or flexible? What are the effects of the outputs on the population and how can we measure them? What is the source of the legitimacy of various parts of the system? Who is supposed to make law, who is supposed to carry it out? How much corruption and maladministration is there and why?

In the best of all possible worlds, one would approach the unresolved questions of law and society armed with answers to these and to countless other questions. Obviously, no one is going to gather all this data; the costs would be enormous, the obstacles insurmountable. But selective research on the legal culture, to answer some specific preliminary questions, seems to be a logical and necessary first step. This is because the legal culture is first of all a major unknown; and second, because legal culture is the key to the effectiveness of law.

Both points are obvious. Opinion research that touches on law is rare. And culture is far more than opinion research in the crudest sense. Legal culture is not "public opinion" as understood by the polls. There is no such thing as the public; for purposes of understanding the law, one must carefully define a relevant public; and its identity will differ as issues differ.

It is clear, however, that the effectiveness of any law, actual or proposed, depends on the response of some public that is sought to be moved, or whose interests seem to be at issue. But response by a public is a cultural factor, and a vital one. The relevant values and attitudes are not easy to get at. If one proposes that some nation adopt for itself an income tax law more or less on the American plan, can one know in advance whether the law will actually work? How much money will it raise, and at what economic and social cost? The dollars and cents that would be raised by a perfectly enforced law can be computed by economists. But one still needs to know the cost from evasion and disobedience, costs that may flow from lack of public support. Italy and the United States are both modern industrial nations; it is notoriously hard to collect income tax in Italy, but not in the United States. Yet it would be no simple matter to discover the precise social conditions that lead to obedience or compliance with particular forms of law (or to respect for law in general) in two countries such as Italy and the United States.

To take another example, litigiousness varies from culture to culture; the social meaning of litigation is different in different countries and sometimes in adjoining villages. What a public agency means to its community should be taken into account when decisions are made to assign particular social tasks to that agency. There is no inherent social role that must be played by any particular institution, or agency. Courts, for example, have been used in many ways in different societies. They have served as instruments to carry into effect decisions and policies of the executive, a use that is apparent in political trials and purges, or in a court such as Star Chamber in Tudor England. They may act as agencies of conciliation and dispute-settlement, as in many traditional societies, and to some extent in American family courts. They may act as oracles of law and makers of law, as is true of Anglo- 
American appellate courts, and in the courts of some theocratic systems. These functions act as both cause and effect of the cultural meanings that surround the idea of judges and courts. And this cluster of cultural meanings in turn determines whether the court can be useful in taking on some slightly different role.

Much of the discussion so far has dealt with engineered social change, a polite way of speaking about change imposed from above. There is, in this approach, a certain danger of treating culture purely as an obstacle. The word culture reminds us of the term "tradition"; and tradition, in modern discourse, is a word often used with a slight sneer. A traditional society is a society which is primitive, torpid, obsolete. It would be unfortunate to think of culture in such a pejorative sense. If one assumes that enacted laws, ideally and magically, ought to work exactly as planned, then culture is indeed an obstacle, since it is the culture which determines the amount of deviance from the norm. But the assumption is of course absurd. One might just as easily assume that no law printed on paper ever came to life without some cultural input; in which case, it is the culture which is the sole source of effectiveness of law.

Modern regulatory law stands in a particularly complex relationship to culture. Most of the research on the effectiveness of law (hence on legal culture) has shied away from this area. Many social scientists have warned of the limits of legal effectiveness; formal changes in law are doomed to failure if they ignore the restraints imposed by custom and culture. But this point of view can be carried much too far. Taken literally, it would mean that important changes in law would be impossible, unless they were preceded by cultural change; and law reform would mean little more than the codification of custom. There are aspects of law which do codify custom; and probably no law is effective that does not make some use of the culture of its society. Still, regulatory law in general is far more than the codification of custom. In a modern state, tax law and the law regulating industry are not really customary law. Law may be able only weakly and slowly to change people's minds on questions that affect their basic drives and values. But it does not follow that the law cannot achieve a particular result, with in a certain culture, by making use of the tools, which work best for that culture.

Attitudes toward law within a community need not act as an obstacle to social change. These attitudes can serve as a tremendous source of strength - a value which can be tapped at low cost or no cost to the government. If people habitually obey the law, for example, high compliance with new regulation can be achieved at very low cost. Imagine trying to assign a value to this aspect of legal culture. Americans, for example, seem willing to pay taxes when they are asked to; they evade, but within acceptable limits. This attitude, and this behavior, have made it possible to raise enormous sums of money through the income tax. And if somewhat more money is needed, it can be raised through adjusting the tax rates upward, with relatively small additional loss through evasion or rebellion. On the other hand, attempts to use law to eliminate adultery in the United States create entirely different problems of enforcement No one obeys adultery laws simply because they are laws. Large segments of the population disapprove of the laws; others feel that these laws are not worth enforcing. Adultery laws, then, have an uphill battle for enforcement; state intervention in private sexual behavior is culturally disapproved. It would require a great input, in real enforcement resources, to raise the rate of effectiveness even a little. At the same time, enforcement would cause costly disruptions in social 
life and raise great public dissatisfaction. The culture, in this case, is a source of cost, of difficulty to anyone who seriously wishes to enforce the laws against adultery. In some societies, "adultery", as defined in the United States, is not even considered immoral, and attempts to ban it by law would be even more futile. In still other societies, adultery is deemed far more serious an offense than in the United States, and violators of the norm are punished swiftly and without social disruption. Even for the United States, where adultery laws are unenforceable, the actual incidence of adultery is limited by the strength of cultural and religious taboos.

Legal research might wish, then, to explore the cultural factors that influence the cost and effectiveness of law. The cost and effectiveness of attempts to bring about economic development through law will be of particular interest. Some countries have achieved very high levels of national income - the United States, Western Europe, Japan, the Soviet Union. Are there elements in their legal culture, which, in partnership with specific economic and social policies, were conducive to economic growth? It there are, can they be transferred or applied to other countries? Or are there functional substitutes that can be tapped in these other countries?

Research on the legal culture might be helpful in increasing our understanding of the cultural specificity or nonspecificity of particular kinds of law, or of whole bodies or codes of law. The twentieth century is an age of cross-cultural influence, of wholesale diffusion of laws and borrowing of legal institutions and codes. Conquerors have often imposed their legal systems on the people they conquered; but only recently, perhaps, have societies borrowed codes, legal systems, and whole bodies of law, in order to upgrade themselves in some way. Japan and Turkey are among the countries that have borrowed Western codes, lock, stock, and barrel. We know that the engineering of social change does not require the replacement of a whole legal system (in the historical-evolutionary sense), or even a whole code. An indigenous system is not inherently incapable of adjusting to the needs and interests of the society. But changing systems is sometimes the only way to ensure the success of a conquest. It might be functional, for example, to stamp out tribal law, if this is the sole way to destroy the power of the chiefs. It might have been right for Ataturk to adopt the Swiss code, to break the political power of Moslem elites. But this is a special sense of the effect of borrowing of laws, and it is one that is not closely related to the content of those laws. It is another question, whether these borrowings are effective in the substantive sense. Under what cultural conditions does borrowing result in real changes in behavior, and under what conditions does it not?

We may apply the term pene $\mathrm{t}$ a $\mathrm{t}$ ion to the degree to which a rule, code, or law takes hold in its population. Penetration refers, then, to the number of actors and spheres of action that a particular rule, legal institution, code, or system of law actually reaches. How far are rules paper rules? Who really governs in the country? How far does the power of the central government extend? What is the living law of the provinces, or the streets, or the corporation, in comparison to the law on the books?

Over the last two centuries there has been a growing tendency for the legal system of the capital, or the central political organs of a country, or its ruling class, to extend its reign deeper down into the population and further out into the land. No community or group is truly lawless. But if law is defined to mean the for- 
mal law of the capital or the rulers, then there are lawless groups and territories in every country. In Africa, the colonialist's law governed, if at all, chiefly in the capital; native or customary law shared power in most of the colony. But there were, and are, equally real dualities in Western countries. The common law was not the law of the English manor; American book law does not really describe the living law of the urban ghettos; the Uniform Commercial Code or a treatise on corporation law do not really illuminate the norms of business behavior. All modern nation-states have been endeavoring, sometimes quite ruthlessly, to increase the degree of penetration of their central legal system, at least geogrphically, usually in other senses too. In the United States, federal rule has been crowding the states, and the tax collectors and the regulators have brought more and more men and affairs into their orbit. In Africa, the new nations have been trying to stamp out their plural legal systems. All countries have been struggling to exert their authority on outlying areas and on more and more of their population. Perhaps some aspects of the rage for increased legal unity, legal penetration, and centralization are less rational than these governments imagine. Active government is an unavoidable necessity in the modern world; a higher degree of legal penetration is therefore equally unavoidable. But not a 11 forms of the imperialism of the center can stand the test of reason. Pluralism, like federalism, is not merely a structural matter. It rests on cultural differences. That is easy enough to see in plural legal systems; but it is even true of a country like the United States, where decentralization has flourished, though not because of any tribal differences between Maine and California. There are, however, aspects of American legal culture that stand in the way of a strong central government, peculiar American attitudes toward government, power, and law. In the light of a country's legal culture, what are the gains and costs of increasing legal penetration? This is a question that badly needs research. The concept must, of course, be further refined. It must be broken down into its components for purposes of measurement and study.

Penetration is a concept of command; it refers to the degree that government is successfully imposed. But government is a two-way street. P a r t i c i p a t i o n is a twin concept of penetration. It refers to the role of members of the general public, or some special public, in making and carrying out law. Juries and elections are forms of participation. Intriguing questions can be asked about participation, similar to questions about penetration. Is a legal system more stable, the more it is participatory? Can a system with more participation more effectively meet demands; or are the costs in lost efficiency too great? Can one define participation in the legal system and measure it?

It is not likely, in the near future, that anyone will prove or disprove propositions made up of concepts so general and abstract, and which cut across most national boundaries, periods, and problems. But these concepts, and others, may provide the vocabulary for more modest proposals in specific fields. If it could be shown, for example, what elements of legal culture are supportive of a collectivized form of land tenure and which of cooperative or individual ownership of land, this would be a major advance in theory, and one of great practical effect. The traditional approaches to foreign law by American lawyers would not be likely to come up with the right kind of hypothesis. Concepts of culture and process may possibly bring better results. 